AGNIESZKA DEJNAKA, KATARZYNA KULIG-MOSKWA, KRZYSZTOF ŁOBOS, JOANNA NOGIEĆ, MIROSŁAWA SZEWCZYK

\title{
Students' perception of attributes of independent colleges of business profile in the market of higher education in Poland
}

Prof. Agnieszka Dejnaka, Katarzyna Kulig-Moskwa, Ph.D., Prof. Krzysztof Łobos, Joanna Nogieć Ph.D., Mirosława Szewczyk, Ph.D. Eng.

WSB University in Wrocław Opole University of Technology

\section{Introduction}

The article aims to recognize the elementary types of attributes which - in the process of evaluation of academic institutions of business profile - are identified by their clients (students). These attributes can potentially offer a strategic indication to decision-makers in independent colleges, since they can be treated as an opinion of the market to be taken into consideration while constructing and modifying the market offer. On the other hand, for public colleges - the natural competitor of non-public academic institutions - they make a source of reflection and the basis to take decisions whether or not to rival the latter, relying on a similar business model or to rather apply a different strategy and offer attributes which are not provided by the sector of non-public schools. The article covers the following sections: independent education in Central Europe and in Poland - transformations, evaluations, the image of a college vs. represented attributes, 
students' expectations towards the college, expectations of different generations regarding higher education, as well as conclusions resulting from the authors' own research.

\section{Non-public education in Central Europe and in Poland - transformations, evaluations}

The year 1989 saw a great change in the sociopolitical system in Poland and a transition from a centrally controlled economy to that of free market and competition. Soon afterwards, there began a dynamic rise in the number of students, which lasted until 2006. It was accompanied by an elevation in the offer of study courses (Sojkin, Bartkowiak, Skuza 2012, pp. 565-581). This also triggered the development of the sector of independent colleges of higher education. Education on the academic level became a mass-scale service in Poland as well as in other states of Central Europe (Vránová 2010, pp. 421-426). Among the consequences of this mass movement the following are frequently mentioned: the lowering of educational standards and maladjustment of the structure of majors completed by graduates to the needs of the market. Low-investment courses, such as those in economy and humanities are still dominant in comparison with other disciplines. Also the unemployment rate among graduates has increased as a result of popularization of higher education (Vránová 2010, pp. 421-426). As regards the educational institution with which the authors are affiliated, it can be noted that it is usually working people who are students there, thanks to which they expand their chances of professional advancement. On the other hand, graduates in the so-called economic majors are to a large extent "absorbed" by the economy, specifically filling executive positions or those connected with sales and management of lower operation levels, which restricts the phenomenon of their enlarging the group of the unemployed. In Poland, the largest of the Central European states, such a boom in the number of LSES students decisively took place between 1994 and 2008. Thus, in the wake of the changes in the socioeconomic system there followed a peculiar democratization and popularization of education on higher level, still - as it turns out - this refers to individuals from low education backgrounds and small towns, not from families with very low incomes, as attending non-public schools is paid for, similarly to extramural courses offered by public colleges (Herbst, Rok 2014, pp. 435-450). Despite all the doubts there exists empirical evidence that popularization of education on the higher level through a rise in the quality

341

AGNIESZKA DEJNAKA, KATARZYNA KULIGMOSKWA, KRZYSZTOF ŁOBOS, JOANNA NOGIEĆ, MIROSŁAWA SZEWCZYK 
of labor resources finds a positive reflection in the form of growth in the GDP per an employed person.

The unfavorable change in the situation in the higher education market after 2007 has been connected with the fact that a number of weak institutions with small numbers of students are being liquidated or taken over by stronger players. There is a consolidation process under way in the higher education system in Poland, both in the public and non-public sectors. It is prognosticated that within the coming 10 years more and more independent academic institutions will be experiencing serious financial problems (Sojkin, Bartkowiak, Skuza 2015, pp. 209224), which will most probably accelerate the consolidation process even more. Thus, the structure of the educational market is changing, with the strongest players remaining in it, as it is easier for them to fulfil the norms imposed by the National Qualifications Framework resulting from the Bologna Process.

\section{The image of a college of higher education}

It is said that the image is the key element, which allows the distinguishing of one firm and its products and services from many others. Organizations not only create their best possible image, but also one which suits the market needs most. Such actions mean that there is a will to adjust the image of the firm to the expectations of its target group.

Even as late as a few years ago there was a belief in the Polish market that creating an image by a college is not congruent with its academic character. That conviction, however, underwent a change together with the appearance of nonpublic academic institutions in the market. They began to create their own images and pay more and more attention to this element. The main aim of the image management was the need to attract students and to differentiate themselves from others. In the opinion of G. Druteikiene, a university which enjoys a good image has a greater competitive advantage over others (Barney 1991, pp. 99-120). This goes in line with the statement that the image of an organization is a greater attribute, the more unique (Rao 1994, pp. 29-44) and the more difficult to copy (Barney 1991, pp. 99-120) it is.

Ever since colleges of higher education realized how important their image is in winning prospective students in the competitive market, they have been taking care of their attractiveness more intensively. Through the intensity of these actions, they caused the role of the image to grow even more, which - in turn - translated into an increase in competitiveness for students between them (Hosseini, Naha 2012, p. 68). This trend, which has been observed in the market 
of academic institutions, indicates that increasing the significance of colleges' image can have a positive influence on the place they occupy in ranking lists (Azoury, Daou, El Khoury 2013). This means that the image has become the key factor to colleges and the marketing policies which they run. Such actions have also caused the significance of the college brand to grow stronger, in the same way as the perception of it by potential students (Sung, Yang 2008, pp. 357-376).

The promotional actions are not limited to merely informing about the educational offer, but are supposed to create positive opinions about individual colleges (Szwacka-Mokrzycka, Abutalibov 2014, pp. 169-179). In order to accomplish this, a college needs a strong and recognizable brand that is part of its image, often in the form of a verbal or graphic symbol, which is more and more often made use of by academic institutions in the Polish educational market. It needs reminding that the idea of creating a trademark in the US higher education market is nothing new, although initially this raised certain apprehensions and dilemmas with reference to this type of institution. However, it must be remembered that all institutions are in need of a strategy to create their own brands so as to be able to succeed in the era of modern marketing (Duesterhaus, Duesterhaus 2014, p. 170). The need for creating a brand by a college of higher education in the Polish market does not provoke controversy any longer. It seems that colleges in Poland have already passed from the first phase, connected with forming strategies of brands, to the second one consisting of their practical realization.

\section{New approach to the university management}

Colleges are part of a competitive market and their existence is decided by the interested party, in particular, client-students and the assets of a college as perceived by them. There is thus the need of a new approach. In the opinion of P. Herr, in today's conditions in a functioning higher level educational market, colleges can successfully use the principles of management of their brand to secure competitive advantage for themselves (Herr, 2008; Lockwood, Hadd 2012).

According to M. Geryk (2012, pp. 133-134), it is of paramount importance "to make efforts to form an organization based on universal values. This needs to be complemented with suitable moral and ethical attitudes of people concentrating around colleges. As regards other institutions of the social structure, colleges of higher education stand out by means of a specific system of values they adhere to". It is also worth quoting A. Kamińska (2015, p. 73), who believes that education is a public good and, what is more, that "the specifics of an academic institution 
consists in its functioning in a given tradition, that is within a commonly accepted set of values and norms of behavior".

From the point of view of a college as an organization, it should be considered in at least two different contexts: as marketing values or social values (Pawłowska, Witkowska, Nieżurawski 2010). Dealing with the problem of assets from the client's viewpoint, the social value is significant, which is defined as a set of features, benefits which the interested group perceives in the college. In the social meaning, the college has an asset when it satisfies the needs of the interested group. An asset is what they consider to be valuable (Masłyk-Musiał 2012, pp. 109-124). In a natural way, if the college fulfils students' expectations, this translates into motivation to study in it. This means that in the Polish market of colleges of higher education, one can observe a dualism of attributes: on the one hand, colleges should preserve a certain academic character and the values attributed to it; on the other one, however, they should aim at attaining effectiveness of management (Geryk 2013, p. 127). The question arises here whether this is possible in practice. Following the changes occurring at the level of higher education in the world, it is evident that such a dualism has already taken place.

Universities are identified with certain academic values which they pass on to their students, and which make the basis of their personal sustainable development (Iqbal, Rasli, Heng, Tat, Bilal Ali, Hassa 2011). Hence, the values represented by the given college and the way it communicates them to the surroundings are essential. Values are thus the foundation of man's life and are modelled by individual preferences and reflections (Wintera, O'Donohue 2012, pp. 565-573). They are often defined as identifiable by both individuals (Ashforth 2001) and organizations (Albert, Whetten 1985, pp. 263-295). Values can create laws and stigmatize improper behaviors and, in consequence, legitimize codes of academic conduct in particular. Values are of the key importance in supporting individuals and institutions in finding the sense of existence in the framework of the past, present and future experience (Henkel 2005, pp. 155-176).

Comprehension of values adhered to by college workers is vital, since it allows modelling their conduct and level of identification with the college. Moosmayer claims that each university lecturer contributes to the value of a college. The other model of academic management takes into account both values of economic and social character. His research (Moosmayer 2012, p. 155) conducted among 1,254 managers working in the environment of academic institutions all around the world revealed that values of the social character are of the key importance to achieving assumed objectives. It also proved that it is essential for 
the academic environment to believe that it is their colleagues, other colleges of higher education and the interested ones who influence the values and behaviors resulting from the former.

The connection between the academic and social attributes is also expressed in each student's feeling part of their college (Anderman, Freeman 2004). They feel accepted and supported by all members of the social environment of the college. Accordingly, an agreement between the college's social and academic goals is significant as it depends on both students' motivations and sense of belonging to the institution, as well as on the very college itself (Kennedy, Tuckman 2013). The above-mentioned considerations indicate that the academic character is a certain set of values which distinguish colleges of higher education from companies dedicated to solely obtaining profit. Among the distinctive values, those of the social character stand out. Despite the visible dualism of the academic and economic values, it can still be concluded that those of the economic nature are not dominant.

\section{Students' expectations of colleges of higher education}

Adjusting colleges' offers of study courses to the needs of the market forces colleges to conduct research into expectations and the motives behind studying. Relevant studies concerning motivations, which were conducted in the Technical University of Warsaw, showed that the following are the most important for students and candidates: chances of getting higher salaries, acquisition of knowledge, finding interesting jobs. Attributes of lesser importance are connected with belonging to the elite, finding new acquaintances and friends, and the very pleasure of studying itself (Masłyk-Musiał 2012, p. 113). In another study, students of the Economic University of Poznan were asked to indicate what attributes another college should possess to make them want to change one University for the other. The largest group of the questioned pointed to the prestige of the diploma of the eventual alternative academic institution (187 indications $-21.06 \%$ of all the answers); second place was taken by greater chances of obtaining practical certificates and vocational qualifications (161 responses - $18.31 \%$ of all the indications) and the third - by staying close to businesspractitioners (125 responses $-14.08 \%$ of all the indications). These three options represent over half of all the responses. Such attributes as: atmosphere of study, knowledge, good teaching personnel, occupy quite distant places as regards the number of responses. It seems thus that the most significant motivation held by people studying nowadays is their wish to find a decent well-paid occupation. 
Students do not tie the prestige of the college to either well-conducted classes or well-prepared personnel (Fazlagić 2012, pp. 7785). As regards the existence and development of a college in the competitive educational market, its image nowadays is gaining a greater and greater significance in the eyes of foreign candidates. It follows on from the research carried out by Woodall and others, that British (native) students have different expectations of colleges from those of foreign students, which determines the image of colleges among candidates from abroad (Woodall, Hiller, Resnick 2014, pp. 48-67).

In turn, the report Future Work Skills 2020, discussing the competences whose role in the labor market will be growing in the future, mentions, among others, the skill of investing actions of one's subordinates with a meaning, digital competence, the skill of processing data and mathematical abilities, interdisciplinary, moving within a multi-cultural environment, project-oriented thinking or adaptability (proficiency at thinking up unconventional solutions) (Future Work Skills 2015). The report called Foresight kadr nowoczesnej gospodarki (Foresight of Human Resources of Modern Economy) prepared by the Polish Agency for Development of Business Activity in 2009 reveals that in a manyyear perspective (10-20 years), both in Poland and in Europe, competences relating to managing knowledge, interpersonal communication, protection of intellectual property will be of value, so will knowledge of information technology, knowledge of foreign and branch languages, and making use of mobile technologies (PARP, 2015).

Empirical research shows that in many domains of knowledge, higher education should be based, to a large extent, on vocational practices and contacts with the reality of performing different professions. This concerns such majors as nursing or construction engineering, but also proves true for accountancy. It turns out that as little as 100 hours of vocational practice in accountancy does increase the effectiveness of teaching vocational subjects related to the domain. In the opinion of the authors of the cited work, this should encourage colleges of higher education to act towards organizing practices of this type for students of accountancy before they take the final exams to complete their studies (Stanley 2013, pp. 779-799).

If we agree to perceive the whole of the educational process as a complex activity consisting of teaching and learning, then the first sphere comprises mainly explicit and theoretical knowledge, the other - one's own work also including practicing the profession. This yields the effects in the form of informal knowledge and experiential knowledge. Such work-based learning that makes use of real contacts within the profession can considerably raise 
graduates' orientation towards cooperating in the vocational environment and applying methods of group work (Tait 2009, pp. 192-197). As it can be presumed, these features are vital in professions which, by their nature, are realized in an organized work environment - in institutions and enterprises, hence - in particular - in professions surrounding business.

\section{The relay of generations and expectations of higher education}

Changing generations and, more specifically - new generations' expectations of the system of higher education, exert a considerable influence on the functioning and perspectives of development of academic institutions in Poland.

As regards organizations and educational systems in the world and in Poland, there are distinguished three generations to be functioning at the moment, that is: "Baby boomers", "Generation X" and "Generation Y". From the point of view of higher education and perspectives of strategic development, "Generation Z" and "Generation a" are also vital, as the former (in a short time to come) and the latter (not until several years from now) will turn into active recipients of services of higher education institutions. The generations can be characterized as follows: 1. "Baby boomers" are a generation of people born in the years 1946-1962, characterized by impatience, a belief in their changing the world; they are innovative, still after many years they return to traditions; the goal of their actions is development, they believe that there are no impossible things and display a small interest in the development of family (Masey 1979).

2. "Generation X" (another name gen-X) stands for people born in the years 19631977, who were the first to get access to computers and the Internet; they are skillful at using computers.

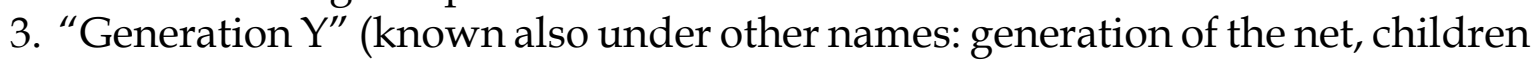
of the net, NetGeneration, GenNetters (Katz 2014) comprises people born in the years 1978-1997 (Cwalina 2001, pp. 54-58) - the first "wired" generation, whose features are: natural use of the Internet (shopping, information, friends - everything is settled on the Internet); they are sure of their own skills, active, oriented towards information, critical (Tapscott 1998). They obtain and analyze information easily, easily make contacts via the Net, do not have difficulty in communicating with others (they know foreign languages); their interests oscillate around strengthening and expressing the identity of the consumerreceiver (Katz 2014).

4. "Generation Z" (other names: Digital Natives, Connected Generation) (Grail Research 2011) is formed of people born in the years 1998-2010, that 
is in the time of the dynamic increase in the significance of the Internet and new communications technologies; for the members of this generation the so-called new technologies have existed "since they can remember" - are something common and casual - it can be said that modern technology makes their natural environment that is indispensable to their effective functioning, the basic point of reference here being the digital world; a world without computers, laptops or smartphones, and what is most important - without access to the Internet - is a real abstraction. Because of their Internet-based activity, they are referred to as Generation M (Multitasking) (Nieustannie podłączeni 2014).

5. "Generation a" - born after 2010, now children who were born in the time of almost Web 3.0, who instead of colored pencils are using tablets, chat on SKYPE and send invitations to their birthday parties in the kindergarten via Facebook; they are "netted" children, "immersed" in digitalization; computers are used by $10 \%$ of three-year-olds, $37 \%$ of four-year-olds and over a half of the five-year-old. The decisive majority (over 90\%) grow up having a computer around and observing how older family members use it - is a conclusion of the latest Diagnoza Społeczna (Social Diagnosis) 2013 (Czapiński, Panek 2014). When the children enter schools, the latter will have to be prepared to teach the former in a different way. They are changes which are happening already now. In most of the US states, the school curricula do not include obligatory teaching of handwriting.

The above-presented definitions emphasize the significance of age as the factor in dividing into individual groups into generations. The criterion of age should not make the main basis for the division of users into individual generations though. Other important factors are also behavioral ones and broadly understood experience of users, along with their skills of perceiving advantages in a longterm perspective. As studies conducted in other countries show, knowledge of generations facilitates both designing strategic education and managing workers in firms (Choain, Dues, Braescu - Kerlan 2012). However, it needs to be underlined that certain features typical of generations are schematic features, thus departures from them may occur, relating to the behavior of individuals within one generation.

Changes stemming from a relay of generations are visible in expectations connected with education, including higher education, with some differences in the respective needs being presented in table 1.

It follows from Table 1 that the most expected manner of education that is common to all the generations are workshops. Coaching is interesting to 
Generations X and Y (Raport Wiek w projekcie 2015). Generation X prefers tasks of hard and soft competences, whose realization time is short. Generation $\mathrm{Z}$ prefers simulation games, mostly those based on rivalry and Internet technology; they do not to want to work on their own on the basis of literature and show little interest in coaching.

Table 1. Expectations held by individual generations of higher education

\begin{tabular}{l|c|c|c|c}
\hline \multicolumn{1}{|c|}{$\begin{array}{c}\text { Gorm of education } \\
\text { Workenation }\end{array}$} & $\begin{array}{c}\text { baby } \\
\text { boomers }\end{array}$ & $\mathbf{X} \%$ & $\mathbf{Y}$ & $\mathbf{Z}$ \\
\hline Simulation games & $17 \%$ & $12 \%$ & $33 \%$ & $27 \%$ \\
\hline Coaching & $12 \%$ & $24 \%$ & $27 \%$ & $27 \%$ \\
\hline $\begin{array}{l}\text { Person's own work on the basis } \\
\text { of literature }\end{array}$ & $10 \%$ & $9 \%$ & $7 \%$ & $9 \%$ \\
\hline Lectures / presentations & $10 \%$ & $10 \%$ & $2 \%$ & $18 \%$ \\
\hline Working on the basis of tutorials & $2 \%$ & $8 \%$ & $7 \%$ & $9 \%$ \\
\hline
\end{tabular}

Source: own study on the basis of Raport Wiek w projekcie (The Report Age in the Project): http://www.dtipolska.com.pl/raport_wiek_w_projekcie.html (accessed on 3.06.2015) and Diagnoza Społeczna (Social Diagnosis) 2013: editors. J. Czapiński, T. Panek, Warszawa 2014: http://analizy.mpips.gov.pl/images/stories/publ_i_raporty/DS2013/Raport_glowny_Diagnoza_ Spoleczna_2013.pdf (accessed on 3.06.2015)

Additionally, Baby boomers, like Generation $Y$, expect great competences and specialist, complex tasks. On the other hand, Generation $\mathrm{Z}$ does not know for sure what knowledge they need, yet tasks ought to be interesting and created by a team. There are no detailed studies carried out relating to Generation a; nevertheless, education of the future is expected to enrich the traditional program with elements of multimedia (28\%) and connecting traditional materials with Internet resources (22\%) (Czapiński, Panek 2014).

Innovative higher education should be prepared strategically for changes not only resulting from the relay of generations, but also those going on in the labor market, where technological progress and virtual and traditional actions intermingle, which also requires competency connected with acquisition and he processing of a large amount of information. Hence, the demand for professions, such as - among others - information broker or e-community manager -will be necessarily supplied. 


\section{Method}

The present studies were conducted on a sample of students from the group of Schools of Banking located in nine large cities of Poland. Thus, they covered a considerable territory of the country, with the dominance of the Western and Southern parts, basically not differing as far as the degrees of industrialization and urbanization are concerned in relation to the other regions.

The School of Banking has carried out cyclical research on attributes of the brand for years. For the needs of the present article the data obtained in the 2013 survey of students, which was realized with the application of Paper and Pencil Interview, was made use of. The students were asked, among other questions, to compare the image of the School of Banking with those of other colleges of higher education in the region, both public and non-public. The evaluations were executed with the use of a 5-grade scale ( $1=$ decisively worse than competitors, $2=$ slightly worse than competitors, $3=$ comparable to competitors, $4=$ slightly better than competitors, $5=$ decisively better than competitors). The sample of the surveyed numbered 7,753 respondents; however, the questionnaires filled in by those who had no opinion were eliminated to - eventually - allow 2,039 to qualify for the analysis.

The application of factor analysis was aimed to reduce the number of variables (attributes) through their peculiar ordering to distinguished factors. This makes it possible to examine the structure of inner dependences of multi-dimensional observations, as well as concluding on general regularities connected with leaving the variables in mutual relations. In this elaboration, the analysis of main components was used. The new variables are called main components (attributes). Each of the main components is a linear function of input variables. The main components are ordered in such a way as to make variations on successive main components smaller and smaller. Variations on the main components measure their resources of information on the examined phenomenon. The sum of variations of all input variables equals the sum of variations of the main components, which means that a conversion of input variables into the main components does not lead to any loss of information on the examined phenomenon. Several of the first main components contain the decisive majority of information on the examined phenomenon, which is provided by input variables. This allows reducing the number of the main components with a possibly small loss of input information. Analysis of the main components was applied as the method of distinguishing attributes (Hill, Lewicki 2007). 


\section{Results}

The results of the factor analysis are presented in Table 2. Calculations allowed the distinguishing of three factors out of 24 variables. It should be noted that the variables from $X_{1}$ to $X_{12}$ describe the result of the comparison of the given feature between the students own college and state-run colleges in the region. In turn, the variables between $X_{13}$ and $X_{24}$ describe the comparison with non-public colleges in the region. Regarding the conducted factor analysis, three attributes explaining in total $65 \%$ of the variations were distinguished.

Table 2. Comparison of mean values and standard deviations; exploratory factor analysis results (factor loadings)

\begin{tabular}{|c|c|c|c|}
\hline Variables (scale 1-5) & Factor 1 & Factor 2 & Factor 3 \\
\hline$X_{1}$ - academic character of the college & 0.203 & 0.785 & 0.132 \\
\hline$X_{2}-$ rich students' life & 0.227 & 0.678 & 0.140 \\
\hline $\begin{array}{l}X_{3}-\text { good organization of study courses and administrative } \\
\text { service }\end{array}$ & 0.287 & 0.222 & 0.732 \\
\hline $\begin{array}{l}\mathrm{X}_{4} \text { - adjustment of education to requirements of employers and } \\
\text { labor market (practicality) }\end{array}$ & 0.238 & 0.508 & 0.535 \\
\hline$X_{5}$ - availability of the college & 0.251 & 0.266 & 0.668 \\
\hline$X_{6}$ - élitist character of the college & 0.141 & 0.800 & 0.188 \\
\hline$X_{7}$ - comfort of studying & 0.277 & 0.316 & 0.726 \\
\hline$X_{8}-$ international character of the college & 0.168 & 0.729 & 0.250 \\
\hline$X_{9}$ - modern character and innovativeness of the college & 0.241 & 0.423 & 0.608 \\
\hline$X_{10}-$ friendly approach to students & 0.314 & 0.186 & 0.758 \\
\hline$X_{11}$ - stability, reliability of the college & 0.227 & 0.684 & 0.347 \\
\hline$X_{12}-$ high quality of education & 0.193 & 0.744 & 0.287 \\
\hline $\mathrm{X}_{13}$ - academic character of the college & 0.763 & 0.137 & 0.114 \\
\hline$X_{14}-$ rich students' life & 0.746 & 0.228 & 0.095 \\
\hline $\begin{array}{l}X_{15}-\text { good organization of study courses and administrative } \\
\text { service }\end{array}$ & 0,756 & 0,109 & 0,270 \\
\hline
\end{tabular}




\begin{tabular}{|c|c|c|c|}
\hline $\begin{array}{l}\mathrm{X}_{16} \text { - adjustment of education to requirements of employers and } \\
\text { labor market (practicality) }\end{array}$ & 0.779 & 0.156 & 0.225 \\
\hline$X_{17}$ - availability of the college & 0.734 & 0.194 & 0.221 \\
\hline $\mathrm{X}_{18}$ - élitist character of the college & 0.791 & 0.162 & 0.187 \\
\hline $\mathrm{X}_{19}$ - comfort of studying & 0.764 & 0.187 & 0.243 \\
\hline$X_{20}$ - international character of the college & 0.754 & 0.249 & 0.101 \\
\hline$X_{21}-$ modern character and innovativeness of the college & 0.774 & 0.213 & 0.192 \\
\hline$X_{22}$ - friendly approach to students & 0.750 & 0.142 & 0.277 \\
\hline$X_{23}$ - stability, reliability of the college & 0.794 & 0.140 & 0.251 \\
\hline $\mathrm{X}_{24}$ - high quality of education & 0.796 & 0.145 & 0.224 \\
\hline Expl. Var & 7.723 & 4.334 & 3.603 \\
\hline Prp. Total & 0.322 & 0.181 & 0.150 \\
\hline
\end{tabular}

The most striking fact regarding the obtained results is that irrespective of what criterion of evaluation we come to deal with (level, exclusive character, stability and reliability, international character, practical profile of the college, comfort of studying, modern character or innovativeness), all of them form one factor when comparisons are made with non-public colleges of higher education in the region - direct competitors of the School of Banking Group. Therefore, students are in no doubt that applying each possible criterion, they rank their own college higher than other non-public competitors and the character of criterion does not matter here at all. This may display a vital clue regarding the fact that in the case of private academic institutions, the individual brand and market image (School of Banking Group enjoys an excellent market opinion) are an important factor in the evaluation. The Group as a whole comprises about 55 thousand students, so apparently this factor also causes individuals to support the collective evaluation in the sense of adjusting to it ("If so many people choose the School of Banking Group, it must be better in every respect than other non-public competitors.") The fact that this is "my college" can be of some importance regarding the obtained result, as well ("It is not necessary to build up a sense of doubt whether or not I did the right thing to choose the offer of this non-public college.") Thus, this factor (Factor 1) comprises all 
the examined variables, so far comparable with other non-public competitors active in the region.

In the case of variables which describe the comparison with public colleges of higher education functioning in the region, there manifested a clear-cut division into two factors: Factor 2 - describing the academic character of studying and Factor 3 - describing comfort of studying in the college, and that connected with employment perspectives after completion. It turns out that while making comparisons with other public colleges, students distinguish between their two features: academic level and leaning to practical applications. Despite the fact that the results of the comparison within the group of criteria referring to the former are still to the advantage of their own college, compared with public academic institutions in the region, the advantage is visible only to an insignificant degree. This may suggest that students are convinced that public colleges are perceived differently in the context of the academic character and this is their traditional attribute. The higher grades allotted to students' own college (see Table 2, where $3=$ comparable to competitors, $4=$ slightly better than competitors) can be dictated by the fact they do not have full knowledge about this issue and often base their opinions on popular beliefs, yet also apply peculiar "reduction of potential doubts". Students are aware of private colleges being not as "academic" as their public counterparts. Nevertheless, most evidently, despite this, they choose a non-public college, which can imply the priority of practical and vocational criteria over the commonly understood and perceived "academic" nature of offers from other institutions.

The third factor is made of variables which describe the practical, vocational character of studying and comfort of studying in the given college and they are variables formed in consequence of comparisons with public colleges of higher education in the region. It can be noticed that, in this respect, students do not have any doubts that they made the right choice. Inasmuch as they rank academic assets in their colleges as minimally better in comparison with public counterparts, they unanimously assess the practical assets higher. The latter are traditionally associated with the offer from non-public colleges and are ranked high in comparison with public colleges. Therefore, if management does not want to deprive potential students of good reasons for studying, they must endeavor to make it very practical. For a college of higher education it is necessary to be either practical or academic, or - which is the best option - both practical and academic - it cannot allow itself not to possess either of these features. It seems that this is a vital practical guideline resulting from research carried out for decision-makers of business colleges in Poland. 


\section{Conclusion}

Perception of attributes of a non-public college of higher education with business profile is the result of, among others, organization of studies, adjustment to labor market, availability of the college, its élitist character, comfort of studying, international character of the college, modern style or quality of education. In the article, results of studies of opinions offered by students of Schools of Banking in Poland are presented. Perception of selected attributes of colleges of higher education is analyzed. The factor analysis with the use of the method of main components distinguished three factors which explain $65 \%$ of the variations of variables: Factor 1 - describing the comparison with non-public colleges, Factor 2 - describing the academic character of studies (comparison with a public college), as well as Factor 3 - describing comfort of studying connected with prospects of employment (comparison with a public college).

To some extent, distinguishing three areas of students' perception can make the basis to formulate the following conclusions:

1. The high grades in the case of each criterion included in the studies and each area (practical profile, comfort, prestige, quality, etc.) which the students allotted to their own non-public college, in comparison with other non-public competitors, can testify that the perception is influenced by the size of the group (because so many students attend this college, its offer cannot be poor) and the brand of the college recognizable in the Polish educational market. Obviously, this does not exclude the opinion being influenced by highly ranked quality of the market offer itself. Goodwill of the non-public academic institution and its position in the market can be an important factor in competitive advantage, especially at the time of demographic depression, when they can be decisive to attractiveness for the diminishing number of candidates. This can matter in the case of both current students and candidates for studies in colleges of higher education.

2. Students of non-public colleges perceive and, as can be supposed, understand on the synthetic level, what academic attributes are. Although they rank their own non-public college higher than public counterparts, the difference is minimal. This can testify to certain doubts which a comparison of public and non-public academic institutions raises regarding the academic character. However, according to the reason in this respect they give priority to practical attributes over academic ones, which in the case of educating "mass" education, in a sense, geared towards "mass" professions - is rational (a practical approach and pragmatism contribute to a higher employment rate 
in professions of this kind of characteristics, while in others more subtle signals, like ones connected with erudition or exceptional intellectual competences, can be decisive).

3. Students of non-public colleges of higher education unanimously rank the practical dimension and comfort of studying higher in comparison with public colleges. Private academic institutions to a greater extent have learned to treat students as clients and to take care of their reception of the offered service and its important features, such as closer contacts with practical application, flexibility, and adjusting to the needs of the labor market. In this respect, public colleges still experience the effects of a certain "ballast of the past", when the student was treated by the college administration and often by the didactic personnel, too, in a way different from the "market" one.

The market-like approach to the offer of studying and adjusting it to expectations of clients-students can raise certain doubts. There appears the question: Which should come first in shaping the attributes of the college: the demand for clients or the educational mission? Which of these is more closely related to creating values as primary ones? Should a college satisfy candidates' expectations or shape them with reference to the future which a young person a student - does not always realize?

\section{Summary}

Students' perception of attributes of independent colleges of business profile in the market of higher education in Poland The article examines the general attributes which are in use by clients (students) in the process of evaluation of non-public colleges of business profile in Poland. The evaluations are presented in comparison with other academic institutions having the same profile, both independent and public ones. In the research part, the method of factor analysis was used with the aim of distinguishing the general values which are in students' use. The most important conclusion resulting from the work is that students of non-public colleges perceive two basic types of attributes regarding a business school, that is practical and academic assets, yet they are most clearly governed by a more pragmatic than academic system of values and choose colleges which - beyond any doubt - offer the model of vocational teaching supported by practice. 
Keywords: $\quad$ academic, practical, generations, students' expectations, market of higher education in Poland.

\section{Streszczenie}

\section{Percepcja atrybutów uczelni niepublicznych o profilu biznesowym przez studentów na rynku szkolnictwa wyższego w Polsce}

Artykuł traktuje o generalnych wartościach będących w użyciu klientów (studentów) w procesie oceny uczelni niepublicznych o profilu biznesowym w Polsce. Oceny te są prezentowane $\mathrm{w}$ porównaniu $\mathrm{z}$ innymi uczelniami wyższymi o profilu biznesowym, tak niepublicznymi jak i publicznymi. W części badawczej zastosowano analizę czynnikową celem wyróżnienie generalnych wartości będących w użyciu studentów. Najważniejszym wnioskiem wynikającym z pracy jest ten, iż studenci uczelni niepublicznych dostrzegają dwa zasadnicze typy wartości szkolnictwa biznesowego, jakimi są wartości praktyczne i wartości akademickie, lecz najwyraźniej kierują się bardziej pragmatycznym niż akademickim systemem wartości i wybierają uczelnie, co do których nie ma wątpliwości, że preferowany jest w nich model nauczania zawodowego wsparty praktykami. Generalnie takie wyniki badań nie powinny zaskakiwać, gdyż znaczna część młodszego pokolenia i osób pracujących w Polsce ma pragmatyczne a nie idealistyczne podejście do życia a dodatkowo intuicyjnie wykazuje przeświadczenie, że studiowanie wsparte praktyką jest bardziej efektywne, co potwierdzają badania innych autorów przytaczane w artykule.

\section{Słowa}

kluczowe: wartości akademickie, wartości praktyczne, pokolenia, oczekiwania studentów, rynek edukacji wyższej w Polsce.

\section{References}

1. Age and Work, Choain, Dues, Braescu - Kerlan 2012: http://www.oecd. org/forum/oecdforum2012adelinebraescu-kerlan.htm.

2. Albert S., Whetten D. (1985), Organizational identity. In L.L. Cummings \& B.M. Staw (Eds.), Research in organizational behaviour, Vol. 7, 263-295.

3. Ashforth B.E. (2001), Role transitions in organisational life: An identity-based perspective. Mahwah, NJ: Lawrence Erlbaum Associates. 
4. Azoury N. M., Daou L. E., El Khoury C. M. (2013). University Image and its Relationship to Student Satisfaction: Case of the Holy Spirit University of Kaslik, Leban, Journal of Executive Education, Vol. 12, Iss. 1.

5. Barney J. (1991), Firm resources and sustained competitive advantage. Journal of Management, 17, 99-120.

6. Customers of tomorrow. Insight and observations About generation Z. Grail Research 2011: http://www.slideshare.net/slideshow/embed_ code/11688637\# .

7. Cwalina W. (2001), Generacja Y - ponury mit czy obiecujaca rzeczywistość, [in:] T. Zasępa, Internet - fenomen społeczeństwa informacyjnego, Częstochowa, 54-58.

8. Czarnecka M. (2012), Webinar, videocast, wiki, Personel i Zarządzanie, No. 7, 18-21.

9. Diagnoza Społeczna 2013, Ed.. J. Czapiński, T. Panek, http://analizy. mpips.gov.pl/images/stories/publ_i_raporty/DS2013/Raport_glowny_ Diagnoza_Spoleczna_2013.pdf.

10. Druteikiene G. (2011), University Image: Essence, Meaning, Theoretical And Empirical Investigation, Global Conference on Business and Finance Proceedings 2011, Vol. 6, No. 2, 167-174.

11. Duesterhaus A., Duesterhaus M. (2014), Attributes of successful university brands in the USA, Journal of Brand Strategy, Vol. 3, Iss. 2, 169-183.

12. Fazlagić J. (2012), Kapitał intelektualny szkoły wyższej z perspektywy studentów: ementor (ementor), Issue: 3 (45), 7785, www.ceeol.com.

13. Future Work Skills, http://www.iftf.org/uploads/media/SR-1382A_ UPRI_future_work_skills_sm.pdf

14. Geryk M. (2012), Społeczna odpowiedzialność uczelni, Oficyna Wydawnicza SGH, Warszawa, 133-134.

15. Geryk M. (2013), Złożoność procesów zarządzania instytucjami szkolnictwa wyższego $i$ ich wptyw na ksztattowanie wartości uczelni jako jednej z miar efektywności zarządzania, Zeszyty Naukowe Uniwersytetu Szczecińskiego, No. 786, 127-134.

16. Henkel M. (2005), Academic identity and autonomy in a changing policy environment. Higher Education, 49, 155-176

17. Herbst M., Rok J. (2014), Equity in an Educational Boom: Lessons from the Expansion and Marketisation of Tertiary Schooling in Poland, European Journal of Education, Vol.49, No. 3 435-450.

18. Herr P. (2008), Higher Education Institutional Brand Value in Transition: Measurement and Management Issues, EDUCAUSE, www.educause.edu

19. Hill T., Lewicki P. (2007), STATISTICS: Methods and Applications. Tulsa, OK.: StatSoft.

20. Hosseini M.H., Naha R.F. (2012). Investigating Antecedents and Consequences of Open University Brand Image, International Journal of Academic Research Vol. 4. No. 4, 68-77. 
21. Enough? International Journal of Inclusive Education, Vol.19, No.3, 303313.

22. Iqbal M.J., Rasli A., Heng L.H., Tat H.H., Ali M.B.B., Hassa I. (2011), Knowledge Economy and University Performance, International Journal of Academic Research Vol. 3. No. 5, I Part.

23. Kamińska A. (2015), Koncepcja modelu polityki informacyjnej uczelni publicznej w kontekście zrównoważonego zarządzania, Zeszyty Naukowe Małopolskiej Wyższej Szkoły Ekonomicznej w Tarnowie, t. 26, No. 1, 71-80.

24. Katz J. (1998), Birth of a Digital Nation, http://www.wired.com/wired/ archive/5.04/netizen.html.

25. Kennedy G.J., \& Tuckman B. W. (2013), An exploration into the influence of academic and social values, procrastination, and perceived school belongingness on academic performance. Social Psychology of Education, 16, 435 - 470. http:/ / dx.doi.org/10.1007/s11218-013-9220-z

26. Lim G., Kim C.U. (2013), Who Has to Pay for Their Education? Evidence from European Tertiary Education, Educational Researcher, Vol. 42, No.4, 250252.

27. Lockwood R. C.; Hadd J. (2012), Building a Brand in Higher Education, GALLUP Business Journal, http://businessjournal.gallup.com/ content/28081/building-brand-higher-education.aspx\#1

28. Masey M.E. (1979), The People Puzzle: Understanding Yourself and Others. Reston, VA: Reston Publishing Co.

29. Masłyk-Musiał E. (2012), Badanie wartości Politechniki Warszawskiej w kontekście strategicznym, Zarządzanie Zasobami Ludzkimi, No. 2, 109-124.

30. Moosmayer D.C. (2012), A Model of Management Academics' Intentions to Influence Values, Academy of Management Learning \& Education, Vol. 11, No. 2, 155-172.

31. Nieustannie podtaczeni - pokolenie Z, http://trendfuture.wordpress. com/2012/02/21/kim-jest-pokolenie-z/

32. PARP, Foresight kadr nowoczesnej gospodarki, (2009). http://www. parp.gov.pl/files/74/81/305/5266.pdf.

33. Pawłowska B., Witkowska, J., Nieżurawski L. (2010), Nowoczesne koncepcje strategii orientacji na klienta, Wydawnictwo Naukowe PWN, Warszawa 2010.

34. Ratajczak, S. (2012), Jakość kształcenia w szkołach wyższych w perspektywie interesariuszy, Dąbrowa Górnicza: Wyższa Szkoła Biznesu w Dąbrowie Górniczej.

35. Rao, H. (1994), The social construction of reputation: Certification contests, legitimation, and the survival of organizations in the American automobile industry: 1895-1912. Strategic Management Journal, 15, 29-44.

36. Sojkin B., Bartkowiak P., Skuza, A. (2015), Changes in Students' Choice Determinants in Poland: A Comparative Study of Tertiary Business Education 
between 2008 and 2013, Higher Education: The International Journal of Higher Education and Educational Planning, Vol.69, No.2, 209-224.

37. Sojkin B., Bartkowiak, P., Skuza A. (2012), Determinants of higher education choices and student satisfaction: the case of Poland. Higher Education. Vol. 63 Issue 5, 565-581.

38. Stanley T., (2013), Bridging the Gap between Tertiary Education and Work: Situated Learning in Accountancy. Issues in Accounting Education. Vol. 28 Iss. 4, 779-799.

39. Sung M., Yang S.U., (2008), Toward the model of university image: The influence of brand personality, external prestige, and reputation. Journal of Public Relations Research, Vol. 20, 357-376.

40. Szwacka-Mokrzycka J., Abutalibov R. (2014), Reating The Image Of The University, Acta Scientiarum Polonorum. Oeconomia, 3 (4) 2014, 169-179.

41. Tait K., (2009), Reflecting on How to Optimize Tertiary Student Learning through the Use of Work Based Learning within Inclusive Education Courses, International Journal of Teaching and Learning in Higher Education, Vol. 20, No. 2, 192-197.

42. Tapscott, D. (1998), Growing Up Digital: The Rise of the Net Generation, McGraw-Hill, New York.

43. Vránová, Š. (2010), Problems Faced by Tertiary Education Graduates in the Labour Market in the Czech Republic. Proceedings of the European Conference on Management, Leadership \& Governance, 421-426.

44. Wintera, R. P.; O'Donohue, W. (2012), Academic identity tensions in the public university: which values really matter?, Journal of Higher Education Policy and Management, Vol. 34, No. 6, 565-573.

45. Woodall, T; Hiller, A; Resnick, S. (2014), Making sense of higher education: students as consumers and the value of the university experience, Studies in Higher Education, 39, No. 1, 48-67. 